\title{
Factors Related to Prelabor Rupture of Membrane among Maternity Mother at Lamongan Regency, East Java, Indonesia
}

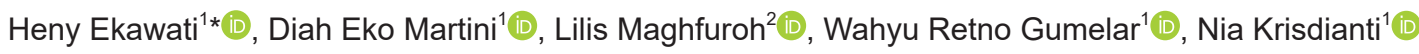 \\ ${ }^{1}$ Department of Maternity Nursing, Universitas Muhammadiyah Lamongan, Lamongan, Indonesia; ${ }^{2}$ Department of Pediatric \\ Nursing, Universitas Muhammadiyah Lamongan, Lamongan, Indonesia
}

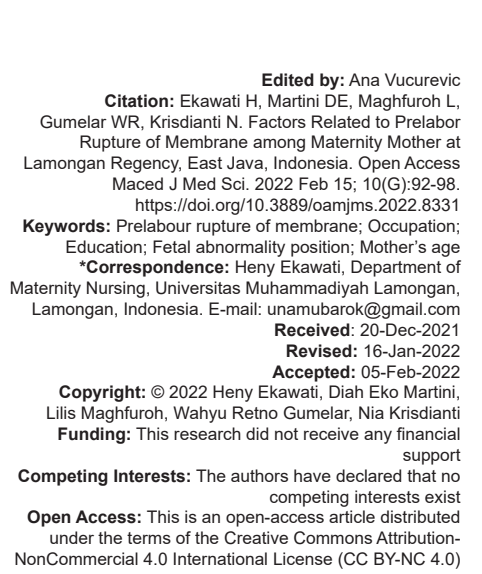

Introduction

Premature rupture of the membrane is prelabour before the beginning of labor or before the age of 37 weeks of pregnancy characterized by painless discharge of fluid coming out of the vagina, discoloration, or decrease in the size of the uterus [1], [2].

The incidence of prelabor rupture of the membrane is estimated to reach $3-10 \%$ of the total delivery and result in the incidence of neonatal death which reaches $40-75 \%$, also increasing the risk of neonate resuscitation, intravenous bleeding, infection, and respiratory distress syndrome and maternal pain due to chorioamnionitis which reaches $17.8 \%$, postpartum period infection, disseminated intravascular coagulopathy, placental solution, national economic losses due to drug costs, hospitalizations, absences at work, and health worker costs [1], [3], [4], [5].

Some studies suggest that increased activity of local cytokines and imbalances in matrix activation of metalloproteinase, oxidative stress, apoptosis, and increased activity of collagenase and proteases, as well as other factors, can cause increased intrauterine pressure leading to prelabor rupture of membrane. This biological process is initiated by various causes including infection/inflammation, placental bleeding, uterine persistence, and genetic polymorphism [6], [7].

In Indonesia, the incidence of prelabor rupture of membrane ranges from $8-10 \%$ of all pregnancies. In term pregnancy, the incidence is between $6 \%$ and $19 \%$ while in preterm pregnancy, the incidence is $2 \%$ of all pregnancies. Even in Manado, it was reported that out of 3810 deliveries at the home of one of the hospitals; there were $1.54 \%$ or 59 cases of prelabor rupture of membrane. About $72 \%$ of premature ruptured amniotic fluid cases occur at the gestational age of more than 37 weeks, with most mothers being in the age range of 20-24 years [8], [9]. While in East Java, the incidence of prelabor rupture of membrane reached 582 incidents $/ 100,000$ live births [6], [10]. In the Lamongan district 2013, 25 people experienced amniotic rupture early/100,000 live births. While in Lamongan Regency, maternity mothers with prelabor rupture of membrane tend to be fluctuating; 
wherein 2017, the incidence of amniotic rupture early amounted to $48.6 \%$ of the total delivery, this figure increased $4.6 \%$ in 2018 to $53.2 \%$. However, in 2019 , it decreased to $29.4 \%$ of total childbirth. Some studies show that the occurrence of early ruptured amniotic fluid is strongly associated with second or third trimester vaginal bleeding, uterine over distance, deficiency of copper and ascorbic acid nutrients, connective tissue disorders, low body mass index, low socio-economic status, smoking, and use of illegal drugs, prior PROM history, history of abortion, and history of urinary tract infections. Nonetheless, often no obvious cause is identified in patients who come with premature ruptured amniotic fluid [6], [10].

Therefore, strong data on factors related to the incidence of premature rupture of the membrane will provide strong evidence for health-care policymakers and caregivers to design programs and strategies to lower the incidence of premature rupture of membrane and prevent complications in both neonatal and maternal.

\section{Research Methods}

This research was used correlational analytics and a cross-sectional approach. Using probability sampling technique, simple random sampling obtained 134 people. The data on age, employment, and education taken from medical records, while for abnormalities in the location of the fetus and the occurrence of premature rupture amniotic fluid taken from the results of ultrasound examinations that have been listed in the medical records on 03-05 May 2021.

\section{Data analysis}

The data were analyzed using the program statistical package of socio science version 24.0. The data presented in a table with a value of 0.05 was considered statistically significant in the study. Chisquare test analysis was used to measure relationships between different variables. Odds ratio (OR) is collected to measure exposure risk.

\section{Results}

Table 1 describes the characteristics of respondents which include the occurrence of premature rupture of membrane, work, education, fetal location abnormalities, and maternal age.
Table 1: Respondent characteristics

\begin{tabular}{lll}
\hline Characteristic & Frequency $(\mathrm{n}=134)$ & Presentation $(\%)$ \\
\hline Premature rupture of membrane & 110 & \\
$\quad$ PROM & 24 & 82.1 \\
$\quad$ Non-PROM & & 17.9 \\
Occupation & 63 & \\
$\quad$ Working & 71 & 47 \\
$\quad$ Not Working & & 53 \\
Education & 47 & 35.1 \\
$\quad$ College & 8 & 6.0 \\
$\quad$ Diploma & 42 & 31.3 \\
Senior High School & 23 & 17.2 \\
Junior High School & 14 & 10.4 \\
Elementary School & & \\
Fetal abnormalities position & 109 & 81.3 \\
$\quad$ Normal Position & 25 & 18.7 \\
$\quad$ Abnormal Position & & \\
Mother's age & 109 & 81.3 \\
$\quad<20$ and>35 & 25 & 18.7 \\
20-35 years & &
\end{tabular}

\section{Discussion}

Based on the results of research in Table 1, it can be known that the frequency of maternity mothers with the incidence of prelabor rupture of a membrane in Lamongan Regency almost entirely (81.3\%) a mother with full-term pregnancy ( $\geq 37$ weeks).

This is following previous studies [1] which stated that about $70 \%$ of cases of premature rupture of membranes occur in term pregnancies, but in referral centers, more than $50 \%$ of cases can occur in preterm pregnancies.

Based on the description above, the researcher assumes that the frequency of the incidence of premature rupture of membranes in Lamongan Regency is directly proportional to the obstetric background and different maternal predispositions such as occupation, location of the fetus, and age. When approaching labor, there is an increase in matrix metalloproteinases which tend to trigger premature rupture of membranes and in the last trimester can cause easy rupture of the membranes due to obstetric and predisposing factors that cause uterine enlargement, uterine contractions, and excessive fetal movement [11]. This opinion is also reinforced by the previous research [12] which states that premature rupture of membranes occurs more frequently in term pregnancy compared to preterm because it is a physiological event, due to increased strain and biochemical and hormonal changes that cause the amniotic membranes to become thinner and more fragile so they break easily.

Based on Table 1, it can be seen that the type of work of mothers with the incidence of premature rupture of membranes in Lamongan is mostly mothers who do not work.

The previous research [12] stated that the occupational status of mothers who were at risk for premature rupture of membranes was mothers who worked during their pregnancy, while the occupational status of mothers who were not at risk was mothers who did not work during their pregnancy or were only housewives. 
For a working mother, it will affect family life as well as her health, especially reproductive health. One of the reproductive health disorders is interference during pregnancy and childbirth. In contrast to mothers who do not work or housewives who have more time to maintain their health and their families, so that the risk of experiencing complications especially premature rupture of membranes during the delivery process is lower [13].

Socio-economic levels proved to greatly affect the physical and psychological health condition of pregnant women. In pregnant women with a good social level, pregnant women will automatically get good physical and psychological well-being [14].

Based on the description above, researchers assume that excessive activity in mothers with risk or non-risk work status causes mothers to experience fatigue which triggers prelabor rupture of membrane.

Based on Table 1, it can be known that the mother's trial with the occurrence of prelabor rupture of a membrane in Lamongan Regency almost half of the mothers has education at the higher education level. This means that the higher the experience of a mother getting an education, it will be more careful in maintaining her pregnancy so that the delivery process can be passed without any circumcision, one of which is amniotic rupture early.

Based on Indonesian Law No. 23, the level of education a person can support or influence the level of knowledge, the higher the level of education, the higher one's knowledge because higher education makes it easier for mothers to receive new information so that they will not be indifferent to health information while the lower the education, the knowledge is very limited so that it is indifferent to existing health programs.

Education is one of the factors that significantly affect household conditions [15]. Mothers with a highly educated background will check their content regularly to prevent complications during childbirth, one of which is to prevent prelabor rupture of a membrane [13].

Based on the above description, researchers assume that mothers who are highly educated are more receptive to information about regular pregnancy screenings, are more aware of meeting vitamin needs, do tetanus toxoid vaccines, and consume nutritious foods. So that highly educated mothers can minimize the occurrence of prelabor rupture of membrane.

Based on Table 1, it can be known that the fetal position with the occurrence of premature rupture in Lamongan Regency is almost entirely a mother with a normal fetal position.

Abnormalities in the fetus can increase the incidence of prelabor rupture of the membrane because the abnormality of the position can allow the tension of the uterine muscles to increase so that it can cause the amniotic rupture early. The smallness of the fetus and the position of the fetus contained do not cause stretching of the amniotic membrane as in normal, breech, or transverse circumstances, because actually what can affect the amniotic rupture early is the strong weakness of the amniotic membrane in holding the fetus [16]. Suhaimi's research says that prelabor rupture of a membrane can be caused because increased apoptosis in the amniotic membrane plays an important role in thinning the fetal membrane that results in the occurrence of prelabor rupture of membrane. An increase in p53 will increase the appearance of caspase-3 which will cause excessive apoptosis with the intention of an increase in the apoptosis process; this can lead to prelabor rupture of a membrane [17].

Characteristics of clinically ruptured premature amniotic fluid include latency from membrane rupture to delivery, increased risk of intrauterine and neonate infections, and oligohydramnios complications. Clinical chorioamnionitis often occurs after prelabor rupture of membrane and increases with decreased gestational age when amniotic rupture. Amniotic rupture before delivery requires immediate attention. An accurate diagnosis and knowledge of gestational age are essential for determining patient management, so it needs serious treatment [18].

Based on the description above, researchers assume that almost all maternity mothers with early amniotic rupture in Lamongan Regency are mothers with normal location; this can be influenced by the age of the mother and the mother's work. This is directly proportional to the age of the mother which is almost entirely mother age is a healthy reproductive age and directly proportional to the work of the mother who is mostly a mother who is not working.

Based on Table 1, it can be known that the age of mothers with premature amniotic events in Lamongan Regency is almost entirely (85.8\%) is a mother with a risky age range ( $<20$ and $>35$ years). The previous research [19] stated that age influences pregnancy and childbirth. The rate of preterm labor is higher among adolescent mothers. These higher rates may be due to an increase in sexually transmitted diseases, a higher prevalence of substance abuse, a lack of preconception counseling, and incomplete maternal physical development. However, based on the previous research conducted by Joseph et al. (2014) mentioned that older women ( $\geq 40$ years) have a greater risk of spontaneous preterm birth compared to women aged 20-24 years.

Based on the description above, researchers assume that the age of the mother during childbirth is almost entirely a healthy reproductive age because they know the age limit of pregnancy and childbirth is good and minimizes the occurrence of risks. In this study, mothers who are not at risk and experience premature ruptured amniotic fluid can be caused by gestational age and the mother's work that drains energy and energy. 
Based on Table 2, the Chi-square results show $p=0.001<0.05$. This proves that there is a relationship of occupational factors with the occurrence of premature rupture of amniotic fluid in maternity mothers in RSI Nashrul Ummah Lamongan Regency. From the results of the OR analysis obtained, the value OR $=5.784$ (OR > 1), Cl: 1.855-18.033 means that respondents whose employment status is at risk of developing amniotic rupture early full-term pregnancy or PROM ( $\geq 37$ weeks) 5.784 times greater than respondents whose employment status is not at risk of developing prelabor rupture of membrane.

Table 2: Relationship of respondent's characteristics with the incidence of premature rupture of membranes among maternity women in Lamongan Regency, East Java, Indonesia

\begin{tabular}{|c|c|c|c|c|c|c|}
\hline \multirow[t]{3}{*}{ Characteristic } & \multicolumn{4}{|c|}{ Premature rupture of membrane } & \multirow[t]{3}{*}{$p$-value } & \multirow[t]{3}{*}{ OR $(95 \% \mathrm{Cl})$} \\
\hline & \multicolumn{2}{|c|}{ PROM } & \multicolumn{2}{|c|}{ Non-PROM } & & \\
\hline & $\mathrm{n}$ & $\begin{array}{l}\text { Presentation } \\
(\%)\end{array}$ & $\bar{n}$ & $\begin{array}{l}\text { Presentation } \\
(\%)\end{array}$ & & \\
\hline \multicolumn{7}{|l|}{ Occupation } \\
\hline Working & 59 & 93.7 & 4 & 6.3 & \multirow{2}{*}{0.001} & 5.784 \\
\hline Not working & 51 & 71.8 & 20 & 28.2 & & $(1.855-18.033)$ \\
\hline \multicolumn{7}{|l|}{ Education } \\
\hline College & 44 & 32.8 & 3 & 2.2 & \multirow[t]{5}{*}{0.000} & \multirow{5}{*}{$\begin{array}{l}0.159 \\
(0.045-0.565)\end{array}$} \\
\hline Diploma & 8 & 6.0 & 0 & 0.0 & & \\
\hline Senior High School & 34 & 25.4 & 8 & 6.0 & & \\
\hline Junior High School & 19 & 14.2 & 4 & 3.0 & & \\
\hline Elementary School & 5 & 3.7 & 9 & 6.7 & & \\
\hline \multicolumn{7}{|c|}{ Fetal abnormalities position } \\
\hline Normal position & 94 & 86.2 & 15 & 13.8 & \multirow[t]{2}{*}{0.018} & 3.525 \\
\hline Abnormal Position & 16 & 64.0 & 9 & 36 & & $(1.321-9.409)$ \\
\hline \multicolumn{7}{|l|}{ Mother's age } \\
\hline$<20$ and $>35$ years & 14 & 73.7 & 5 & 14.2 & \multirow[t]{2}{*}{0.334} & \multirow{2}{*}{$\begin{array}{l}0.554 \\
(0.178-1.722)\end{array}$} \\
\hline $20-35$ years & 96 & 83.5 & 19 & 85.8 & & \\
\hline
\end{tabular}

In line with the previous research, there is a relationship between the mother's employment status and the incidence of prelabor rupture of a membrane with $p=(0.019)<0.05$ and obtained the value $\mathrm{OR}=0.091(\mathrm{OR}>1), \mathrm{Cl}: 0.011-0.755$ means that respondents whose employment status is at risk of prelabor rupture of a membrane 0.091 times greater than respondents whose employment status is not at risk of prelabor rupture of a membrane.

This study is also in line with the previous research [20] with the results of statistical tests using Chi-square showing the value of Asymp.Sig $p=0.014<0.05$ with housewife occupation status or mother who not working 33 people $(73.3 \%)$ stating that there is a significant relationship between the occupation of maternity mothers and prelabor rupture of a membrane.

The pattern of work done by pregnant women can affect the normal energy needs needed. Excessive work during pregnancy with a length of work that exceeds $3 \mathrm{~h}$ can result in fatigue. Fatigue at work causes weak chorion and amniotic so that it can be the trigger for the occurrence of prelabor rupture of the membrane [20].

Based on the description above, researchers assume that working, in general, will require a lot of time and energy. Pregnant women, who work too hard and long, travel from home to work that is not safe or too far away and also the mother's activities at work such as going up and down stairs can cause the mother fatigue and the mother's physical condition will weaken so that it will affect the condition of her pregnancy. Pregnant women should not do too much activity, but the condition of every pregnant woman is different there are strong and some are weak. The burden of a lot of the mother's work will also affect the psychic that can make the mother stressed.

Based on Table 2, it can be known that the Chi-square result shows $p=0.002<0.05$. This proves that there is a relationship of educational factors with the occurrence of prelabor rupture of a membrane in maternity mothers in the Lamongan Regency. From the results of the OR analysis obtained, the value $\mathrm{OR}=0.159(\mathrm{OR}>1), \mathrm{Cl}: 0.045-0.565$ means that respondents who are not high-education experienced premature ruptured amniotic fluid 0.159 times greater than respondents who are highly educated are not at risk of developing premature rupture amniotic fluid.

This study is following research conducted [21] showing the results of the OR statistical test by 2.43 (Cl 95\%. 1.32-4.49) which means that mothers with uneducated ones are 2.43 times more likely to experience premature ruptured amniotic fluid compared to educated mothers.

In line with other studies [22] showed that there is a significant relationship between education and the incidence of amniotic rupture early with $p=0.000<0.05$ and obtained $\mathrm{OR}=3.632(2.264-5.827)$ meaning that respondents who are not highly educated are at risk of developing premature rupture amniotic fluid. About 3.632 are more likely than highly educated people. The study also showed that education is the most dominant independent variable factor that influences the occurrence of premature ruptured amniotic fluid with multivariate regression results obtained $p=0.000<0.05$ and obtained $\mathrm{OR}=3.606$.

Maternal education is one of the causes of maternal death. Women with higher education tend to be more aware of the health of themselves and their families and are aware of nutrition and health checks during pregnancy. In addition, women with higher education will be better able to detect early danger during pregnancy. Another study also showed that women's formal education affects the use of maternal health services. In Thailand, maternal education greatly influences the use of health services. Mothers with higher education when suffering from premature rupture of membranes immediately come to health services because they know it can affect their health and their babies [22].

Based on the description above, the researcher assumes that education affects the mindset of a mother. Although almost all of the mothers' ages in this study were of healthy reproductive age, namely, 20-35 years, this was inversely proportional to the education they received. Because education affects the maturity of the soul and mind of a mother to understand the importance of carrying out a pregnancy check regardless of the conditions that 
befall her which also affects the learning process and consideration of the best decisions for their health and safety them and their babies, the higher the education, the more positive aspects are obtained. This can minimize the occurrence of premature rupture of membranes in maternity and if a prelabor rupture of membranes occurs, the mother's coping is better when dealing with the condition than mothers who do not have high educated.

Based on Table 2, it can be known that the results of statistical tests of this data do not qualify for the Chi-square test so the alternative test is Fisher's exact test. The test results show $p=0.018<0.05$. This proves that there is a relationship between fetal position abnormalities and the incidence of premature rupture of membranes in women giving birth at Lamongan Regency. From the results of the OR analysis, the value of $\mathrm{OR}=3.525(\mathrm{OR}>1), \mathrm{Cl}: 1.321-9.409$ means that respondents with normal fetal position experienced premature rupture of membranes 3.525 times greater than respondents with fetal position abnormalities experienced premature rupture of membranes.

In line with other studies [23] showed that there is a relationship between fetal abnormality and the incidence of prelabor rupture of membrane $(p<0.05$; $\mathrm{OR}=6.942$ [Cl 95\%: 1.139-42.325]). This means that mothers who experience fetal abnormalities are at risk of 6.942 times greater to experience premature ruptured amniotic fluid compared to mothers who do not experience fetal location abnormalities.

This study is also following other studies [24] that there is a relationship between malposition (malpresentation) of the fetus with the incidence of prelabor rupture of a membrane with $p=(0.019)<0.05$ and obtained the value of OR $=10.946(\mathrm{OR}>1)$, $\mathrm{Cl}$ : 1.325-90.400 meaning that respondents with fetal malposition are at risk of developing premature rupture amniotic fluid. About 10.946 times greater than respondents who did not malposition the fetus experienced premature ruptured amniotic fluid.

In line with the previous research [22], it was shown that there was a significant association between malposition and abnormality of fetal location and the incidence of prelabor rupture of a membrane with $p=0.000<0.05$ and obtained OR $=2.960$ (2.769-3.832). In malposition, the lowest positions of the fetus do not cover the birth canal, so there is no resistance to the amniotic membrane that causes the leaking of the amniotic membrane.

According to the researchers, pregnant women with fetal abnormalities can cause uterine pressure directly at the bottom of the uterus that will make the amniotic membrane rupture. In addition, there are at-risk ages, risky jobs, and uneducated mothers in pregnant women with fetal abnormalities in this study, so the chance of premature amniotic rupture is greater.

Based on Table 2, it can be seen that the results of the statistical test of this data do not meet the requirements of the Chi-square test so that an alternative test is carried out, namely, the Fisher's exact test. The test results show $p=0.334<0.05$. This proves that there is no relationship between maternal age abnormalities and the incidence of prelabor rupture of membranes in women giving birth in Lamongan Regency. From the results of the OR analysis, the value of $\mathrm{OR}=0.554(\mathrm{OR}>1), \mathrm{Cl}: 0.178-1.722$ means that respondents who are at risk for premature rupture of membranes are 0.554 times greater than respondents with age who are not at risk for prelabor rupture of membranes.

The study is in line with the previous research [25] mentioning that the frequency of prelabor rupture of membrane mostly occurs at the age of $17-18$ years $(46.7 \%)$ showing statistical test results with $p=0.496$ which means there is no significant association between maternal age and the incidence of prelabor rupture of membranes.

The studies on other studies [26] also stated that there was no association between maternal age and the incidence of prelabor rupture of membrane based on the results of the Chi-square test obtained results $p=0.503>0.05$.

Mothers who are <20-years-old can cause problems in their reproductive organs this is because at that age is not yet fully formed, the ligaments that prevent the uterus have not functioned optimally and are not too strong so that the possibility of prelabor rupture of membrane or other complications can occur. While at the age of the mother $>35$ years of pregnancy is usually followed by degenerative diseases such as high blood pressure or diabetes mellitus. The degenerative disease will indirectly affect the process of pregnancy and childbirth of the mother and baby [27]. Mother who has older age resulted in reduced ovum quality and can reduce the quality of offspring so that pregnancy in old age has a greater chance of complications, especially amniotic rupture early [28].

According to the researchers, the incidence of prelabor rupture of a membrane can occur both in mothers with risk ages ( $<20->35$ years) and in pregnant women who are not at risk ages (20-35 years). It is influenced by the obstetric background of different mothers. The results showed no significant association between age and the incidence of prelabor rupture of the membrane because the study was more influenced by occupation factor, fetal abnormalities position, and maternal education.

\section{Conclusion}

Based on the discussion above, the factors related to premature rupture of membranes are 
occupation, education, maternal age, and fetal position abnormalities. The recommendation from this study is to consider the influence of factors related to premature rupture of membranes in pregnant women to minimize complications that may occur to the mother and baby, so health workers always try to improve the quality of health services, especially antenatal care to detect factors associated with the occurrence of premature rupture of membranes.

\section{Ethical Approval}

This research has been reviewed and received approval from the Health research ethics commission of Muhammadiyah Lamongan University with Number 117/EC/KEPK-S2/12/2020.

\section{References}

1. Assefa NE, Berhe H, Girma F, Berhe K, Berhe YZ, Gebreheat G, et al. Risk factors of premature rupture of membranes in public hospitals at Mekele city, Tigray, a case control study. BMC Pregnancy Childbirth. 2018;18(1):386. https://doi.org/10.1186/ s12884-018-2016-6

PMid:30268103

2. Workineh $\mathrm{Y}$, Birhanu S, Kerie S, Ayalew E, Yihune M. Determinants of premature rupture of membrane in Southern Ethiopia, 2017: Case control study design. BMC Res Notes. 2018;11(1):927. https://doi.org/10.1186/s13104-018-4035-9 PMid:30587239

3. Addisu D, Melkie A, Biru S. Prevalence of preterm premature rupture of membrane and its associated factors among pregnant women admitted in Debre Tabor General Hospital, North West Ethiopia: Institutional-based cross-sectional study. Obstet Gynecol Int. 2020;2020:4034680. https://doi. org/10.1155/2020/4034680

PMid:32508927

4. Dars S, Malik S, Samreen I, Kazi RA. Maternal morbidity and perinatal outcome in preterm premature rupture of membranes before 37 weeks gestation. Pak J Med Sci. 2014;30(3):626-9. https://doi.org/10.12669/pjms.303.4853

PMid:24948992

5. Yu H, Wang X, Gao H, You Y, Xing A. Perinatal outcomes of pregnancies complicated by preterm premature rupture of the membranes before 34 weeks of gestation in a tertiary center in China: A retrospective review. Biosci Trends. 2015;9(1):35-41. https://doi.org/10.5582/bst.2014.01058 PMid:25787907

6. Dayal S, Hong PL. Premature rupture of membranes. In: Stat Pearls. Treasure Island, FL: Stat Pearls Publishing; 2021.

7. Lannon SM, Vanderhoeven JP, Eschenbach DA, Gravett MG, Waldorf KM. Synergy and interactions among biological pathways leading to preterm premature rupture of membranes. Reprod Sci. 2014;21(10):1215-27. https://doi.org/10.1177/1933719114534535 PMid:24840939
8. Lowing JG, Lengkong R, Mewengkang M. Overview of premature rupture at rsup prof. Dr. R. D. Kandou manado. E-Clin. 2015;3(3):741-4. Available from: https://www.ejournal. unsrat.ac.id/index.php/eclinic/article/view/9418 [Last accessed on 2021 Nov 17].

9. Syarwani TI, Tendean HM, Wantania JJ. Overview of the early ruptured amniotic event (KPD) at Prof. Dr. R.D. Kandou Manado Hospital in 2018. Med Scope J MSJ. 2020;1(2):24-9. Available from: https://www.ejournal.unsrat.ac.id/index.php/msj/article/ view/27462 [cited 2021 Nov 17]

10. Tiruye G, Shiferaw K, Tura AK, Debella A, Musa A. Prevalence of premature rupture of membrane and its associated factors among pregnant women in Ethiopia: A systematic review and meta-analysis. SAGE Open Med. 2021;9:1-9. https://doi. org/10.1177/20503121211053912

PMid:34733510

11. Chen J, Khalil RA. Chapter four-matrix metalloproteinases in normal pregnancy and preeclampsia. In: Khalil RA, editor. Progress in Molecular Biology and Translational Science. United States: Academic Press; 2017. p. 87-165. Available from: https:// www.sciencedirect.com/science/article/pii/S1877117317300509 [Last accessed on 2021 Nov 04].

12. Rohmawati $\mathrm{N}$, Wijayanti $\mathrm{Y}$. Amniotic rupture early at ungaran regional general hospital. HIGEIA J Public Health Res Dev. 2018;2(1):23-32.

13. Mariza A. Educational Relations dan Socio-Economic Dengan Incidence of Anemia Pthere are Pregnant Womenln Bps T Yohan Way Halim Bandar Lampung in 2015; 2016.

14. Jacobus EH, Kindangen P, Walewangko EN. Analysis of factors yang affect household poverty in North Sulawesi. J Pembang Ekon Keuang Drh. 2021;19(3):86-103.

15. Rahayu B, Sari AN. Descriptive study of causes of prelabour rupture of membrane (KPD) in Maternity mothers. J Ners Midwifery Indones. 2017;5(2):134-8.

16. Suhaimi D. Protein P53 as a risk factor for prelabour rupture of membrane. Indones J Appl Sci. 2012;2(2):83-5. Available from: http://www.jurnal.unpad.ac.id/ijas/article/view/2738 [Last accessed on 2021 Nov 16].

17. Mercer BM. Premature rupture of the membranes. In: Protocols for High-Risk Pregnancies. New Jersey, United States: John Wiley \& Sons, Ltd; 2020. p. 461-74

18. De Sadovsky AD, Matijasevich A, Santos IS, Barros FC, Miranda AE, Silveira MF. Socioeconomic inequality in preterm birth in four Brazilian birth cohort studies. J Pediatr (Rio J). 2018;94(1):15-22. https://doi.org/10.1016/j.jped.2017.02.003 PMid:28572019

19. Joseph K, Fahey J, Shankardass K, Allen VM, O'Campo P, Dodds $\mathrm{L}$, et al. Effects of socioeconomic position and clinical risk factors on spontaneous and iatrogenic preterm birth. BMC Pregnancy Childbirth. 2014;14(1):117. https://doi. org/10.1186/1471-2393-14-117 PMid:24670050

20. Hastuti H, Sudayasa IP, Saimin J. Analysis of risk factors for prelabour rupture of membranes at arkmas general hospital. MEDULA. 2017;3(2):268-72. Available from: http://www.ojs. uho.ac.id/index.php/medula/article/view/2553 [Last accessed on 2021 Nov 16].

21. Maryuni M, Kurniasih D. Risk factors of premature rupture of membrane. Kesmas J Kesehat Masy Nas Natl Public Health J. 2017;11(3):133-7.

22. Wulandari E. Analysis of Risk Factors for Early Rupture of Amniotic Fluid in Childbirth at Tugurejo Hospital Semarang. Indonesia: UNIMUS; 2016. Available from: http://www. repository.unimus.ac.id/278 [Last accessed on 2021 Nov 17]

23. Nurfianto S, Hadi U, Purnomo W. Relationship between maternal 
age, gravida and gestational age with premature rupture of membrane in adolescent pregnancy. Indian J Forensic Med Toxicol. 2019;13:756.

24. Padila. Maternity Nursing Teaching Book: In Accordance with Competency Standards (PLO) and Basic Competencies (CLO). Indonesia: Nuha Medika; 2014.

25. Wulandari IA, Octaviani A, Febrianti M. Factors related to early rupture amniotic events (KPD) in RSIA sitti khadijah I makassar in 2019. J Kesehat Pomegranate Pelamonia. 2019;3(1):52-61.

26. Maharrani T, Nugrahini EY. Relationship of Age, Parity with Premature Rupture of Membranes at Jagir Health Center
Surabaya. J Penelit Kesehat Suara Forikes J Health Res Forikes Voice. 2017;8(2):102-8.

27. Cavazos-Rehg PA, Krauss MJ, Spitznagel EL, Bommarito K Madden T, Olsen MA, et al. Maternal age and risk of labor and delivery complications. Matern Child Health J. 2015;19(6):1202-11. https://doi.org/10.1007/s10995-014-1624-7

PMid:25366100

28. Panjaitan IM, Tarigan AM. The characteristic relationship of maternity mothers with amniotic fluid broke early at Martha Friska Hospital. A community midwife. Midwife Community. 2018;1(2):67-75. 